GRASAS Y ACEITES 71 (4)

October-December 2020, e382

ISSN-L: 0017-3495

https://doi.org/10.3989/gya.0809192

\title{
Fatty acid profile, mineral content and bioactive compounds of cocoa spreads supplemented with baru almonds (Dipteryx alata Vog.)
}

\author{
M.L.L. Campidellia ${ }^{\mathrm{a},}$, J.D. Souza Carneiro ${ }^{\mathrm{a}}$, E.C. Souza ${ }^{\mathrm{a}}$, M.L. Magalhães ${ }^{\mathrm{a}}$, \\ G.L. dos Reis ${ }^{\mathrm{a}}$ and E.V.B. Vilas Boas ${ }^{\mathrm{a}}$ \\ ${ }^{a}$ Federal University of Lavras - UFLA, Lavras, Minas Gerais, Brazil. \\ Corresponding author: marina.lamounier@yahoo.com.br
}

Submitted: 27 August 2019; Accepted: 13 November 2019; Published online: 14 October 2020

\begin{abstract}
SUMMARY: The present study aimed to perform a chromatographic and spectrophotometric characterization of the bioactive compounds, antioxidants, phenolics, profile of fatty acids and minerals in spreads supplemented with different contents of baru almonds. The addition of baru almonds ( 1 treatment) enhanced the concentrations of vitamin $\mathrm{C}$, antioxidants, gallic acid, calcium, magnesium, sulfur, manganese and oleic acid. In contrast, the absence of this oil in P3 treatment resulted in an increase in the concentrations of vanillin, $p$-coumaric acid, ferric acid, $o$-coumaric acid, linoleic acid and saturated and polyunsaturated fatty acids. When the tannin, beta-carotene/linoleic acid, trans-cinnamic acid, monounsaturated fatty acids, hypocholesterolemic and hypercholesterolemic fatty acid contents and atherogenic and thrombogenic indices were evaluated, no significant $(\mathrm{p}>0.05)$ differences were detected between treatments.
\end{abstract}

KEYWORDS: Bioactive compounds; Brazilian Cerrado; High-Performance Liquid Chromatography; New Products; Oilseeds

RESUMEN: Perfil de ácidos grasos, contenido mineral y compuestos bioactivos de untables de cacao suplementados con almendra baru (Dipteryx alata Vog.). El presente estudio tuvo como objetivo realizar la caracterización cromatográfica y espectrofotométrica de compuestos bioactivos, antioxidantes, fenólicos, perfil de ácidos grasos y minerales en productos para untar suplementados con diferentes contenidos de almendra baru. La adición de almendra baru (tratamiento P1) potenció las concentraciones de vitamina C, antioxidantes, ácido gálico, calcio, magnesio, azufre, manganeso y ácido oleico. En contraste, la ausencia de este aceite en el tratamiento $\mathrm{P} 3$ proporcionó un aumento en las concentraciones de vainillina, ácido $p$-cumarico, ácido férrico, ácido $o$-cumarico, ácido linoleico y ácidos grasos saturados y poliinsaturados. Cuando se evaluó el contenido de tanino, betacaroteno/ácido linoleico, ácido trans-cinámico, ácidos grasos monoinsaturados, contenido de ácidos grasos hipo- e hiper-colesterolémicos e índices aterogénicos y trombogénicos, no se detectaron diferencias significativas $(\mathrm{p}>0.05)$ entre los tratamientos.

PALABRAS CLAVE: Cerrado Brasileño; Compuestos bioactivos; Cromatografía líquida de alta resolución; Nuevos Productos; Semillas oleaginosas

ORCID ID: Campidelli MLL https://orcid.org/0000-0002-0127-2943, Souza JDC https://orcid.org/0000-0003-40605891, Sousa EC https://orcid.org/0000-0002-3369-4892, Magalhães ML https://orcid.org/0000-0001-8006-2487, Reis GL https://orcid.org/0000-0001-9313-1349, Vilas Boas EVB https://orcid.org/0000-0002-0252-695X

Citation/Cómo citar este artículo: Campidelli MLL, Souza JDC, Sousa EC, Magalhães ML, Reis GL, Vilas Boas EVB. 2020. Fatty acid profile, mineral content and bioactive compounds of cocoa spreads supplemented with baru almonds (Dipteryx alata Vog.). Grasas Aceites 71 (4), e382. https://doi.org/10.3989/gya.0809192

Copyright: (C2020 CSIC. This is an open-access article distributed under the terms of the Creative Commons Attribution 4.0 International (CC BY 4.0) License. 


\section{INTRODUCTION}

Brazil is recognized worldwide for the plant biodiversity of its forests, boasting hundreds of species that provide edible seeds, nuts, and almonds. These foods stand out due to their sensory characteristics, making them suitable for the development of new products with economic potential (Carvalho et al., 2012).

The baru almond (Dipteryx alata Vog.) is an oleaginous native of the Cerrado biome and stands out due to its high nutrient density, its high market value and because it is part of an abundant genetic heritage, but it is not well studied. Previous studies demonstrated the presence of important chemical/ bioactive compounds in this almond, such as monounsaturated fatty acids (linoleic and oleic), boron, zinc, copper, manganese, magnesium, antioxidant molecules, polyphenols (catechin, rutin and gallic acid, caffeic acid, chlorogenic acid, o-coumaric and trans-cinnamic acid), sterols and vitamins $\mathrm{C}$ and $\mathrm{E}$ (alpha and gamma tocopherols) (Lemos et al., 2012; Pinelli et al., 2015; Lemos et al., 2016; Campidelli et al., 2019; Campidelli et al., 2020).

The in vivo effect of the baru almond has been previously tested, and it has been proven that consumption can reduce adiposity, improve lipid profile, and increase antioxidant enzyme activity (Souza et al., 2016). These characteristics, along with its chemical properties (cited above), can minimize the incidence of different metabolic disorders, making the baru almond a health-effective food.

Due to recent evidence supported by scientific trials, cocoa is also a beneficial food for consumer health. Its high content in bioactive compounds has positive effects on improving lipid function, digestion, kidney function, and heart function, as well as anemia and mental fatigue. These benefits can be achieved due to its antioxidant, anti-inflammatory and antiplatelet action (Dilliinger et al., 2000; Herbello-Hermelo et al., 2018).

Among other options, oilseeds and cocoa products are also used in hazelnut spreads, and are extensively consumed due to their high acceptability. A disadvantage of these spreads is that they contain high concentrations of sugar and low percentages of oilseeds, harming the consumer who wishes to obtain health benefits. In addition, hazelnuts are included in the major food groups responsible for triggering food allergies (Holzhauser et al., 2002); a practical alternative would be to replace them. The baru almond is a potential substitute for hazelnut due to its chemical composition and additional physiological health benefits.

The agri-food sector monitors changes in the nutritional landscape and is interested in developing new products which are specific to meeting individual needs. Moreover, the search for information that explains how these products are beneficial is a new goal to be achieved. Nonetheless, research into the effectiveness of these new products is limited and to our detriment, there is a distribution of products below the initial quality proposed.

The present study aimed to make a chromatographic and spectrophotometric characterization of bioactive compounds, antioxidants, phenolics, fatty acids and mineral profile in spreads comprising differing contents of baru almonds.

\section{MATERIALS AND METHODS}

\subsection{Reagents, materials and experimental design}

All chemicals, reagents and solvents used were of analytical or high-performance liquid chromatography (HPLC) grade and obtained from SigmaAldrich (St. Louis, MO, USA). Deionized water $(>18 \mathrm{M} \Omega . \mathrm{cm})$ was obtained from a Milli-Q system (Millipore, Brussels, Belgium).

Baru almonds were obtained from the Cerrado biome, located in the city of Barra do Garças-MT, during the harvest season (between August and September, 2016). The baru almond has the following centesimal composition (g/100g): 6.63 moisture, 22.96 protein, 31.73 lipid, 14.44 dietary fiber and 1.55 ashes.

The following raw materials were used for the manufacture of baru almond spreads: Baru almond (Local producer of the city of Barra do Garças, Brazil), Hazelnut (À Granel® - Lavras, Brazil), Erythritol (Tovani® - São Paulo, Brazil), Coconut Oil (Copra ${ }^{\circledR}$ - Maceió, Brazil), Skimmed Milk Powder (Molico $\AA^{\circledR}$ - Caçapava, Brazil), 100\% Cocoa Powder (Garoto ${ }^{\circledR}$ - Vila Velha, Brazil), Polydextrose (Tovani ${ }^{\circledR}$ - Santana, Brazil) (Tovani ${ }^{\circledR}$ - Santana, Brazil), Emulsifying and Flavoring (Duas Rodas ${ }^{\circledR}$ - Campinas, Brazil).

Three spread formulations were developed with different baru almond contents, as follows: 35\% baru almond spread (P1); spreads with $17.5 \%$ baru and $17.5 \%$ hazelnut (P2); and control spread with $0 \%$ baru almond and 35\% hazelnut (P3) (Table 1). The choices of the ingredients used in the processing of the spreads was made through previous tests (for example focus group) that aimed to match the sensorial and technological characteristics. As for the experimental design, this was completely randomized with three replicates. Three independent batches were used for each treatment.

\subsection{Spread processing}

The drying of baru almonds and hazelnuts in an air circulation oven (Marconi ${ }^{\circledR}$, MA0351, Piracicaba, Brazil) was carried out at $105^{\circ} \mathrm{C}$ for $30 \mathrm{~min}$. Thereafter, both oilseeds were ground in a home processor (Philipis Walita ${ }^{\circledR}$, RI7632, Varginha, Brazil) for $5 \mathrm{~min}$. Then, in the same 
TABLE 1. Formulation of the spreads with different contents of baru almond

\begin{tabular}{lccc}
\hline & \multicolumn{3}{c}{ Treatments } \\
\cline { 2 - 4 } Ingredients (\%) & P1 & P2 & P3 \\
\hline Baru almond & 35 & 17.5 & 0 \\
Hazelnut & 0 & 17.5 & 35 \\
Erythritol & 29.5 & 29.5 & 29.5 \\
Coconut oil & 14 & 14 & 14 \\
Skim powdered milk & 5.6 & 5.6 & 5.6 \\
Cocoa 100\% & 10.4 & 10.4 & 10.4 \\
Polydextrose & 3 & 3 & 3 \\
Whey & 1 & 1 & 1 \\
Emulsifier & 1 & 1 & 1 \\
Flavoring & 0.5 & 0.5 & 0.5 \\
\hline
\end{tabular}

processor, the remaining ingredients (Erythritol, coconut oil, skim powdered milk, cocoa $100 \%$, polydextrose, whey, emulsifier and flavoring - Table 1) were added and homogenized with the oleaginous seeds for a further $3 \mathrm{~min}$. The obtained spread was packed in transparent polyethylene packages and stored at $12{ }^{\circ} \mathrm{C}$ in temperature controlled chambers (Eletrolab ${ }^{\circledR}$, EL202, Sao Paulo, Brazil). Thereafter, the analytical determinations described below were performed in triplicate.

\subsection{Determination of bioactive compounds}

We evaluated the total content of phenolic compounds, tannins and vitamin $\mathrm{C}$. The hydroalcoholic extract was prepared according to the methodology adapted from Milardovic et al., (2005), except for vitamin $\mathrm{C}$, which followed the methodology proposed by Roe; Kuether (1943).

Total phenolics were determined by the Folin-Ciocalteu reagent method, using gallic acid $\left(0.024-0.096 \mathrm{mg} \cdot \mathrm{mL}^{-1}\right)$ as the standard for the calibration curve. The sample $(0.5 \mathrm{~mL})$ and $2.0 \mathrm{~mL}$ of sodium carbonate $\left(75 \mathrm{~g} \cdot \mathrm{L}^{-1}\right)$ were added to $2.5 \mathrm{~mL}$ of $10 \%(\mathrm{v} / \mathrm{v})$ Folin Ciocalteu reagent. After $30 \mathrm{~min}$ reaction at $37{ }^{\circ} \mathrm{C}$, the absorbance was measured using an ultraviolet (UV)-visible spectrophotometer (Varian Cary ${ }^{\circledR}, 50$, Campinas, Brazil) at 765 $\mathrm{nm}$. The results were expressed in $\mathrm{mg}$ of gallic acid equivalents (GAE) per $100 \mathrm{~g}^{-1}$ (Roe; Kuether, 1943).

The total phenolic compounds were also evaluated using diazonium salt Fast Blue BB, with standard gallic acid $\left(0.096-0.024 \mathrm{mg} \cdot \mathrm{mL}^{-1}\right)$ for the calibration curve. The extract $(0.5 \mathrm{~mL})$ was added to $0.10 \mathrm{~mL}$ of Fast Blue BB reagent $(0.1 \%)$ and 0.10 $\mathrm{mL}$ of $\mathrm{NaOH}(5 \%)$. After $60 \mathrm{~min}$ of the reaction in the dark at room temperature, the absorbance was measured using a UV-visible spectrophotometer
(Varian Cary ${ }^{\circledR}, 50$, Campinas, Brazil) at $420 \mathrm{~nm}$. The results were expressed in mg gallic acid equivalents (GAE) per $100 \mathrm{~g}^{-1}$ (Palombini et al., 2016).

In order to quantify antinutritional compounds, the tannin content was measured by the colorimetric method according to the Association of Official Analytical Chemists (AOAC, 1990). The method was based on the intensity of the blue color produced in reducing the Folin-Denis reagent for phenols, and was then measured using a UV-visible spectrophotometer (Varian Cary ${ }^{\circledR}, 50$, Campinas, Brazil) at $760 \mathrm{~nm}$. The results were expressed as equivalents of catechin.

The analysis of vitamin $\mathrm{C}$ content was carried out according to the 2.4-dinitrophenylhydrazine colorimetric method and measured using a UV-visible spectrophotometer (Varian Cary ${ }^{\circledR}, 50$, Campinas, Brazil) at $520 \mathrm{~nm}$ and the results were expressed as equivalents of ascorbic acid (Roe; Kuether, 1943).

The antioxidant activity was evaluated by the DPPH• (2.2-diphenyl-1-picrilhidrazil radical) scavenging method, and measured using a UV-visible spectrophotometer (Varian Cary ${ }^{\circledR}, 50$, Campinas, Brazil) at $517 \mathrm{~nm}$ (Milardovic et al., 2005). The scavenging activity of the DPPH radical was expressed as the inhibition percentage (\% I), where Ac is the control absorbance and Aam the sample absorbance, according to the equation: $\% \mathrm{I}=(\mathrm{Ac}-\mathrm{Aam}) /$ Ac $\times 100 \%$. The minimum concentration of sample that inhibited $50 \%$ DPPH radical $\left(\mathrm{IC}_{50}\right)$ in the reaction medium was obtained by a linear regression using concentration versus percentage inhibition values.

The antioxidant activity determination by $\beta$-carotene/linoleic acid was conducted according to the methodology described by Miller (1971) and read at $470 \mathrm{~nm}$ using a UV-visible spectrophotometer (Varian Cary®, 50, Campinas, Brazil). The results were expressed as a percentage of inhibition of oxidation.

\subsection{Individual identification of phenolic compounds by high-performance liquid chromatography with diode-array detection (HPLC-DAD)}

The statements for the individual identification of phenolic compounds were prepared following the methodology described by Lemos et al., (2012). Quantification and identification of these phenols were performed in liquid chromatography (HPLC-DAD/UV-Vis) (Shimadzu Corp. ${ }^{\mathbb{R}}$, model Shimadzu, Kyoto, Japan). The mobile phase consisted of $2 \%(\mathrm{v} / \mathrm{v})$ acetic acid in deionized water (mobile Phase) and 70:28:2 (v/v) methanol/water/ acetic acid (mobile phase B), and phenolics were detected at $280 \mathrm{~nm}$. Phenolic compounds were identified by the comparison of retention times with standards (gallic acid, catechin, chlorogenic acid, caffeic acid, vanillin, $p$-coumaric acid, ferulic 
acid, $m$-coumaric acid, o-coumaric acid, trans-cinnamic acid, quercetin and rutin). The results were expressed as $\mathrm{mg}$ of phenolic compound in $100 \mathrm{~g}$ of fresh weight.

\subsection{Profile of fatty acids by CG-FID}

For the fatty acid profile analysis, lipids from spreads were extracted according to the procedures described by Folch et al., (1957). The analysis was performed by gas chromatography on a Shimatzu CG 2010 chromatograph (Agilent Technologies Inc., Palo Alto, CA, USA), equipped with a flame ionization detector, split injection at the rate of 1:50 and capillary column SPTM-2560 Supelco, $100 \mathrm{~m}$ $\times 0.25 \mathrm{~mm} \times 0.20 \mu \mathrm{m}$ (Supelco Inc., Bellefonte, PA, USA). The initial temperature of the column was $140{ }^{\circ} \mathrm{C}$, which was maintained for 5 min, changing to $240{ }^{\circ} \mathrm{C}$ with increments of $4{ }^{\circ} \mathrm{C}$, held for $30 \mathrm{~min}$ for a total of $60 \mathrm{~min}$. The injector and detector were kept at a temperature of $260{ }^{\circ} \mathrm{C}$ and helium was used as the carrier gas. The fatty acids identified were compared to the retention times presented by the chromatographic pattern SupelcoTM37 FAME Mix (Supelco Inc., Bellefonte, PA, USA) and were expressed in percentage $(\%)$ of the total fatty acids. They were then grouped as saturated fatty acids (SFA), monounsaturated fatty acids (MUFAs) and polyunsaturated fatty acids (PUFAs). The atherogenic index (AI) and thrombogenic index (TI) were determined in accordance with that specified by Ulbricht and Southgate (1991), as the Eq. (1 and 2): AI: $[(\mathrm{C} 12: 0+(4 \times \mathrm{C} 14: 0)+\mathrm{C} 16: 0)] /$
$\quad(\Sigma \mathrm{MUFAs}+\Sigma \Omega 6+\Sigma \Omega 3)$

TI: $(\mathrm{C} 14: 0+\mathrm{C} 16: 0+\mathrm{C} 18: 0) /[(0.5 \times \Sigma \mathrm{MUFAs})+$ $(0.5 \times \Sigma \Omega 6)+(3 \times \Sigma \Omega 3)+(\Sigma \Omega 3 / \Sigma \Omega-6)]$

The ratio of hypocholesterolemic and hypercholesterolemic fatty acids $(\mathrm{h} / \mathrm{H})$ was calculated according to the formula described by Santos-Silva (2002) and shown in Eq. (3):

$$
\begin{gathered}
\text { h/H: }(\mathrm{C} 18: 1+\mathrm{C} 18: 2+\mathrm{C} 20: 4+\mathrm{C} 18: 3+\mathrm{C} 20: 5+ \\
\text { C22:5+C22:6)/(C14:0+C16:0) }
\end{gathered}
$$

\subsection{Mineral composition}

The mineral analysis described by the Sarruge and Haag method (Sarruge; Haag, 1974) was used in nitric-perchloric acid digestion at $50{ }^{\circ} \mathrm{C}$ for $10-15$ min and then at $100{ }^{\circ} \mathrm{C}$ to digest all material. Then, the content levels of boron, sulfur, phosphorus, potassium, calcium, magnesium, zinc, copper, manganese and iron were quantitatively evaluated using an atomic absorption spectrophotometer (Perkim Elmer $\AA$, 3110, Wellesley, United States) at 248.3 $\mathrm{nm}$. The data were described in $\mathrm{mg} \cdot 100 \mathrm{~g}^{-1}$.

\subsection{Statistical analysis}

The results were subjected to an analysis of variance (ANOVA), and tests for comparison of averages (Tukey's 5\% probability of error). Statistical calculations were performed using the program Râ version 5.0. The differences were considered significant when $\mathrm{p}<0.05$. The principal components analysis (PCA) was used to comprehend the similarity among the edible coatings in relation to key nutritional parameters by the program Chemoface (Nunes et al., 2012).

\section{RESULTS AND DISCUSSION}

\subsection{Determination of bioactive compounds}

The content of total phenolic compounds, tannins, vitamin C, DPPH• and beta-carotene/linoleic acid from food spreads prepared with different baru almond contents are described in Table 2.

Of the bioactive compounds listed in Table 2, it was possible to observe that the P1 treatment presented a higher content of vitamin $\mathrm{C}(\mathrm{P} 1-$ $24.37 \mathrm{mg} \cdot 100 \mathrm{~g}^{-1}, \mathrm{P} 2-19.80 \mathrm{mg} \cdot 100 \mathrm{~g}^{-1}$ and P3 $18.25 \mathrm{mg} \cdot 100 \mathrm{~g}^{-1}$ ) and a higher antioxidant activity $(\mathrm{p}<0.05)$ as measured by DPPH• $(\mathrm{P} 1-9.83 \mathrm{~g}$ of DPPH sample $\mathrm{g}^{-1}, \mathrm{P} 2-11.87 \mathrm{~g}$ of DPPH sample $\cdot \mathrm{g}^{-1}$ and P3 - $19.45 \mathrm{~g}$ of DPPH sample. $\mathrm{g}^{-1}$ ). As the baru almond was the main raw material in this treatment, it is worth mentioning that this oleaginous product provided an enhancement in the bioactivity of these molecules (when compared to other treatments). When evaluating the $\mathrm{P} 2$ treatment, it was found that P1 did not present a statistical difference $(p<0.05)$ when total phenolic compounds were evaluated by the two methods (method Folin Ciocalteau: P1 - $343.60 \mathrm{mg} \cdot 100 \mathrm{~g}^{-1} \mathrm{GAE}, \mathrm{P} 2-346.66 \mathrm{mg} \cdot 100 \mathrm{~g}^{-1}$ GAE and P3 - $225.89 \mathrm{mg} \cdot 100 \mathrm{~g}^{-1} \mathrm{GAE}$; method Fast Blue: P1 - $46.80 \mathrm{mg} \cdot 100 \mathrm{~g}^{-1}$ GAE, P2 $45.05 \mathrm{mg} \cdot 100 \mathrm{~g}^{-1} \mathrm{GAE}$ and P3 - $33.26 \mathrm{mg} \cdot 100 \mathrm{~g}^{-1}$ GAE), indicating that the use of a mix containing $50 \%$ of baru almond and $50 \%$ of hazelnut favors the presence of these substances. On the other hand, when the presence of tannins and antioxidant capacity measured by beta-carotene/linoleic acid were evaluated, no significant difference was detected among treatments $(\mathrm{p}<0.05)$.

In reference to the results obtained for total phenolic compounds (measured by the Folin Ciocalteau method), these substances were high in the developed spreads. It was possible to verify that, when compared to $\mathrm{P} 1$, treatment with $\mathrm{P} 3$ gave a decrease of $34.25 \%$ in these molecules, indicating that the inclusion and exclusion of baru almonds (P1 and P3, respectively) may have reduced the presence of phenolic compounds $(\mathrm{p}<0.05)$. The obtained values of phenolic compounds in other oilseeds show an average content of $32,46,47,137$ and $239 \mathrm{mg} \cdot 100 \mathrm{~g}^{-1}$ 
TABLE 2. Mean values of total phenolic compounds (measured by Folin Ciocalteau and Fast Blue BB), tannins, vitamin C, $\mathrm{DPPH} \bullet$ and beta-carotene/linoleic acid present in food spreads made with different levels of baru almonds

\begin{tabular}{|c|c|c|c|c|}
\hline \multirow[b]{2}{*}{ Analytical Determinations } & \multicolumn{3}{|c|}{ Treatments ${ }^{(2)}$} & \multirow[b]{2}{*}{$\mathbf{P}$} \\
\hline & P1 & $\mathbf{P 2}$ & P3 & \\
\hline Total Phenolic Compounds (Folin Ciocalteau) GAE Ge $^{(3)}\left(\mathrm{mg} \cdot 100 \mathrm{~g}^{-1}\right)$ & $343.60 \pm 0.32^{\mathrm{a}}$ & $346.66 \pm 0.43^{\mathrm{a}}$ & $225.89 \pm 0.54^{\mathrm{b}}$ & 0.0001 \\
\hline Total Phenolic Compounds (Fast Blue BB) GAE ${ }^{(3)}\left(\mathrm{mg} \cdot 100 \mathrm{~g}^{-1}\right)$ & $46.80 \pm 0.43^{\mathrm{a}}$ & $45.05 \pm 0.72^{\mathrm{a}}$ & $33.26 \pm 0.98^{\mathrm{b}}$ & 0.0012 \\
\hline Tannins $\mathrm{CE}^{(4)}\left(\mathrm{g} \cdot 100 \mathrm{~g}^{-1}\right)^{\mathrm{ns}}$ & $622.19 \pm 1.73$ & $645.24 \pm 0.88$ & $517.96 \pm 1.93$ & 0.5535 \\
\hline Vitamin $C^{(5)}\left(\mathrm{mg} \cdot 100 \mathrm{~g}^{-1}\right)$ & $24.37 \pm 0.24^{\mathrm{a}}$ & $19.80 \pm 0.45^{\mathrm{b}}$ & $18.25 \pm 1.47^{\mathrm{b}}$ & 0.0040 \\
\hline DPPH・ IC50 (g of DPPH sample.g ${ }^{-1}$ ) & $9.83 \pm 0.92^{\mathrm{c}}$ & $11.87 \pm 0.40^{\mathrm{b}}$ & $19.45 \pm 0.99^{\mathrm{a}}$ & 0.0002 \\
\hline Beta-carotene/linoleic acid $(\% \text { protection })^{\mathrm{ns}}$ & $87.54 \pm 1.11$ & $85.39 \pm 0.86$ & $84.90 \pm 1.24$ & 0.5297 \\
\hline
\end{tabular}

${ }^{1}$ Mean values \pm standard deviation (in quadruplicate, $n=4$ ). Values labeled with different letters in the same line are significantly different (Tukey's test at 95\% significance; $\mathrm{p}<0.05) ;{ }^{2}$ Treatments: P1 (100\% baru almond and $0 \%$ hazelnuts), P2 (50\% baru almond and $50 \%$ hazelnuts) and P3 (0\% baru almond spread 100\% hazelnuts); ${ }^{3}$ GAE: Gallic Acid Equivalents; ${ }^{4}$ Catechin equivalents; ${ }^{5}$ Expressed in $\mathrm{mg}$ of ascorbic acid; ns: not significant ( $\mathrm{p}>0.05)$; P: p-value.

for pine nuts, macadamia, nuts, almonds, cashew nuts and brazil nuts, respectively (Kornsteiner et al., 2006). The developed spread had higher amounts of phenolic compounds than the baru almond itself, because according to Fráguas et al., (2014) it has $228.24 \mathrm{mg}$ of phenolic compounds in $100 \mathrm{~g}$. The drying process of oilseeds, which provides exposure and increases the availability of these compounds (Lemos et al., 2012), as well as the connection with other substances such as cocoa, which stands out for its considerable presence of polyphenols $\left(308 \mathrm{mg} \cdot 100 \mathrm{~g}^{-1}\right.$ ) (Giacometti et al., 2016), may contribute to the increase in these molecules. Pinelli et al., (2015) found $86.16 \mathrm{mg} / 100 \mathrm{~g}$ of phenolic compounds in cookies made from $100 \%$ de-fatted baru almond flour. The removal of fat as well as the roasting process resulted in a considerable reduction in the presence of these bioactive molecules.

A similar behavior was observed when using the Fast Blue BB method, where P1 and P2 were statistically similar $(p<0.05)$ and differed from P3 $(p<$ 0.05 ). However, this method provided a reduction in the detection of phenolic substances. This evidence is attributed to the fact that this procedure is specific and unique in the quantification of phenols, since the reagents used do not complex with other substances, like proteins, sugars or other reducing compounds such as ascorbic acid (as in the method of Folin Ciocalteau) (Naczk; Shahidi et al., 2004). Despite providing a lower result regarding the presence of phenolic compounds, this methodology has been verified to be more accurate because it provides the exclusive dosage of these compounds.

Tannins were observed in considerable amounts in all the spreads and no statistical difference was detected ( $\mathrm{p}>0.05)$, indicating that the type of oleaginous seed (baru almond and hazelnut) also contributed to the presence of these molecules. According to Campidelli et al., (2020) and Efraim et al., (2011), baru almonds, hazelnuts and cocoa, which were the major ingredients in all the spreads, are considerable sources of this element. Efraim et al., (2011) explained that cocoa seeds contain a complex series of procyanidins, formed from the condensation of individual units of catechins or epicatechins (called monomers) which are responsible for the formation of tannins in this food. Tannin compounds are considered a potent antioxidant and have antimutagenic and anticancer properties (Chu et al., 2016). These substances are beneficial when consumed in correct dosages and research confirms that the bioactivity of these compounds is attributed primarily to their ability to minimize the action of free radicals through the interception of active oxygen. Pinelli et al., (2015), when developing a cookie with $100 \%$ defatted baru almond flour, found $37.32 \mathrm{mg} \cdot 100 \mathrm{~g}^{-1}$ of tannins. The high temperature, to which these products were subjected, could potentially be responsible for the minimization of these molecules.

Since they belong to a group of phenolic compounds, they present high reactivity and are associated with the prevention of diseases related to oxidative stress. Delfino and Canniatti-Brazaca (2010) explained that the abundant consumption of this substance must be controlled, since there is compromise in the use of minerals and proteins causing anti-nutritional effects. However, since oilseed consumption generally does not occur in natural form (mainly due to the sensorial aspect it presents in this condition), the process of drying them (which was the primary stage of processing) becomes an important step in the development of sensory aspects and reduction in unhealthy substances.

It was found that $\mathrm{P} 1$ presented the highest content of vitamin $\mathrm{C}$. In addition, $\mathrm{P} 2$ and $\mathrm{P} 3$ were not statistically different $(\mathrm{p}<0.05)$. The absence of baru almonds (in P3) caused a $25 \%$ reduction in this element (when compared to P1), indicating that this oleaginous seed can contribute directly to the presence 
of this vitamin because, according to Campidelli et al., the baru almond has $39.14 \mathrm{mg} \cdot 100 \mathrm{~g}^{-1}$ of vitamin C. Even with the reductions, it was found that the developed spreads had a high content of vitamin $\mathrm{C}$. The consumption of $100 \mathrm{~g}$ of the spread contributes to $27.07 \%$ (P1), $22.0 \%$ (P2) and $20.27 \%$ (P3) of the Reference Daily Intake (RDI) developed by the Food and Nutrition Board at the National Academies Institute of Medicine Recommended Daily Intake (which is $90 \mathrm{mg}^{-1}$ for an adult male) (Institute of Medicine, 2000). According to this same recommendation, these substances, when ingested at the appropriate dosages, may provide physiological benefits to the body of a normal adult individual since ascorbic acid is a preventive antioxidant. In addition to being an important natural antioxidant, vitamin $\mathrm{C}$ acts as a co-factor of several enzymes in the human body. Due to their inability to synthesize vitamin $\mathrm{C}$, humans need to acquire this substance through diet, and a lack of vitamin $\mathrm{C}$ may result in diseases such as scurvy and pernicious anemia (Traber; Stevens, 2011).

With regard to the means obtained for antioxidant capacity, it was considered that there was sequestering activity of DPPH $\bullet$ with a statistical difference in all treatments $(\mathrm{p}<0.05)$. However, it was observed that P1 hads higher values, because the lower the $\mathrm{IC}_{50}$, the greater the antioxidant activity of the compound (Pelvan et al., 2018). Due to treatments P2 and P3 having lower amounts of baru almonds (when compared to $\mathrm{P} 1$ ), they demonstrated a respective reduction of $20.75 \%$ and $97.89 \%$ antioxidant capacity. This reduction may be compatible with the antioxidant composition of hazelnuts. In addition, the interaction of this oleaginous seed with cocoa, which has high antioxidant activity (Hernández-Hernández et al., 2018), allowed for the quantification of antioxidants in these spreads (even if values below P1).

Some compounds do not react with free DPPH • due to being lipophilic and are therefore difficult to characterize. The total antioxidant activity was also measured by the beta-carotene/linoleic acid system and the results for this determination can be classified as: (i) high levels $(>70 \%)$; ii) intermediate $(40-70 \%)$ and iii) low $(<40 \%)$ in the inhibition of oxidation, according to Hassimoto et al., (2005). All the developed spreads demonstrated high levels and no statistical difference $(\mathrm{p}<0.05)$ in lipophilic antioxidants, showing that both oleaginous seeds contributed to the presence of these substances. These results are important because oxidative processes (which are precursors of several chronic noncommunicable diseases) can be avoided by the use of antioxidant substances that have the property of preventing or reducing the triggering of unwanted reactions (Dillinger et al., 2000). According to Campidelli et al., (2020), baru almonds exhibited $91.7 \%$ protection, demonstrating that much of the antioxidant capacity of pastes comes from them.

\subsection{Individual identification of phenolic compounds by HPLC-DAD}

10 phenolic compounds were detected in the three treatments, including flavonoids (catechin) and non-flavonoids (gallic acid, chlorogenic acid, vanillin, p-coumaric acid, o-coumaric acid, ferulic acid, trincinnamic acid and rutin). The results associated with the identification and quantification of these molecules are shown in Table 3 and the highest results were obtained for gallic acid (P1 $31.26 \mathrm{mg} \cdot 100 \mathrm{~g}^{-1}, \mathrm{P} 2-24.26 \mathrm{mg} \cdot 100 \mathrm{~g}^{-1}$ and $\mathrm{P} 3$ $\left.-10.14 \mathrm{mg} \cdot 100 \mathrm{~g}^{-1}\right)$, catechin $\left(\mathrm{P} 1-32.46 \mathrm{mg} \cdot 100 \mathrm{~g}^{-1}\right.$, $\mathrm{P} 2-31.95 \mathrm{mg} \cdot 100 \mathrm{~g}^{-1}$ and $\mathrm{P} 3-14.75 \mathrm{mg} \cdot 100 \mathrm{~g}^{-1}$ ) and chlorogenic acid $\left(\mathrm{P} 1-8.80 \mathrm{mg} \cdot 100 \mathrm{~g}^{-1}, \mathrm{P} 2-7.61\right.$ $\mathrm{mg} \cdot 100 \mathrm{~g}^{-1}$ and $\mathrm{P} 3-1.31 \mathrm{mg} \cdot 100 \mathrm{~g}^{-1}$ ).

Among the phenols identified by HPLC, rutin, catechin and gallic acid, which have antioxidant capacity, were the major phenolics present in the spreads. It was found that some of the components present in the spreads (gallic and caffeic acid) showed increased mean values $(p<0.05)$ through the addition of baru almonds (P1 treatment) and one of the possible explanations is associated with the fact that this is an oleaginous source of phenolic substances. Campidelli et al., (2020), evaluated the profile of phenolic compounds in baru almonds, and found that rutin, gallic acid and caffeic acid were the major compounds in this profile. A significant increase $(\mathrm{p}<0.05)$ in ferulic acid, vanillin, rutin and an unpublished quantification of $p$-coumaric acid in P3 treatment was also observed and this result was attributed to the use of hazelnuts in this formulation. According to Pelvan et al., (2018) this oleaginous seed is also a source of these components. Regarding trans-cinnamic acid, no significant difference $(p<0.05)$ was observed between the treatments, indicating that the use of baru almonds and hazelnuts may also contribute to the inclusion of these elements in the spread.

The results obtained are not only due to the presence of baru almonds and hazelnuts, but also through the inclusion of cocoa, which in turn is also considered a source of phenolic substances (Hernández-Hernández et al., 2018). The authors affirm that the presence of phenolic compounds in cocoa confered antioxidant properties, and prevented the formation of free radicals which act in the process of the development of non-transmissible chronic degenerative diseases (HernándezHernández et al., 2018). The high presence of these substances in foods is important because they are able to attribute health benefits due to the broad spectrum of medicinal properties they present and has been found that processed spreads can be considered food sources of phenolic compounds.

Żyżelewicz et al., (2018) investigated the profile of phenolic compounds in chocolates made with $100 \%$ cocoa liquor and also found gallic acid as the 
TABLE 3. Identification and quantification by HPLC-DAD/UV-Vis of phenolic compounds present in food pastes made with different contents of baru almonds ${ }^{1}$

\begin{tabular}{|c|c|c|c|c|c|}
\hline \multirow[b]{2}{*}{ Phenolic Compound } & \multirow[b]{2}{*}{ Chemical Structure } & \multicolumn{4}{|c|}{ Treatments $\left(\mathrm{mg} .100 \mathrm{~g}^{-1}\right)^{(2)}$} \\
\hline & & P1 & $\mathbf{P 2}$ & P3 & $\mathbf{P}$ \\
\hline Gallic Acid & & $31.26^{\mathrm{a}}$ & $24.26^{\mathrm{b}}$ & $10.14^{\mathrm{c}}$ & 0.0070 \\
\hline Catechin & & $32.46^{\mathrm{a}}$ & $31.95^{\mathrm{a}}$ & $14.75^{\mathrm{b}}$ & 0.0001 \\
\hline Chlorogen Acid & & $8.80^{\mathrm{a}}$ & $7.61^{\mathrm{a}}$ & $1.31^{\mathrm{b}}$ & 0.0001 \\
\hline Caffeic Acid & & $0.93^{\mathrm{a}}$ & $0.60^{\mathrm{b}}$ & $0.16^{\mathrm{c}}$ & 0.0030 \\
\hline Vanillin & & $0.65^{\mathrm{b}}$ & $0.57^{\mathrm{b}}$ & $1.14^{\mathrm{a}}$ & 0.0001 \\
\hline$p$-coumaric & & - & - & 0.02 & 0.0001 \\
\hline Ferrulic Acid & & - & $0.13^{\mathrm{b}}$ & $0.7^{\mathrm{a}}$ & 0.0001 \\
\hline$o$-coumaric & & - & - & 0.42 & 0.0001 \\
\hline Trans-cinnamic Acid & & 1.70 & 1.64 & 1.55 & 0.2389 \\
\hline Rutin & & $38.42^{\mathrm{b}}$ & $45.32^{\mathrm{a}}$ & $44.66^{\mathrm{a}}$ & 0.0001 \\
\hline
\end{tabular}

${ }^{1}$ Mean values (in quadruple, $\mathrm{n}=4$ ). Values followed by different letters in the same line show differences by Tukey's test at $95 \%$ significance ( $\mathrm{p}<0.05)$; ${ }^{2}$ Treatments: P1 (100\% almond baru and $0 \%$ hazelnuts), P2 (50\% almond baru and 50\% hazelnuts) and P3 (0\% almond baru paste $100 \%$ hazelnuts); ns: not significant at the level ( $\mathrm{p}>0.05)$; P: $\mathrm{p}$-value. 
major compound ( $325.73 \mathrm{mg} .100 \mathrm{~g}^{-1}$ ), followed by epicatechin $\left(192.31 \mathrm{mg} \cdot 100^{-1}\right)$. The superiority of these results over those obtained in this study is due to the fact that the cocoa used was $100 \%$ pure, thus increasing its bioactivity.

\subsection{Profile of fatty acids by CG-FID}

The determination of the fatty acid profile present in food spreads supplemented with different levels of baru almonds is shown in Table 4.

Unsaturated fatty acids, including oleic and linoleate acids, were found to be predominant and a significant difference between treatments $(\mathrm{p}<0.05)$ was detected (acid oleic: P1 - 57.85\%, P2 - 37.20\%, P3 $27.52 \%$; and acid linoleate: P1 - 6.66\%, P2 - 9.24\%, P3 $-13.46 \%$ ). A high presence of monounsaturated fatty acids was also observed. This same profile was found in baru almonds, since high concentrations of monounsaturated fatty acids were quantified, particularly oleic acid (Campidelli et al., 2020).

The Dietary Guidelines for Americans (2016) states that the daily intake of MUFAs should be at least $33 \mathrm{~g}^{-1}$ (for a $2000 \mathrm{kcal}$ diet) and, in this regard, the intake of $100 \mathrm{~g}^{-1}$ of spread corresponding to $\mathrm{P} 1, \mathrm{P} 2$ and $\mathrm{P} 3$ can respectively provide $1.8,1.5$ and 0.9 times this recommendation. Research indicates that oilseeds are sources of these compounds and both baru almonds and hazelnuts contributed $(\mathrm{p}<0.05)$ to this profile. Ingestion of these fats is recommended by experts as there is scientific evidence that proves they can reduce the risk of cardiovascular disease, be effective in weight loss and contribute to lowering low-density lipoprotein (LDL) levels in the blood without affecting high-density lipoprotein (HDL) levels (Lottenberg, 2009).

As for saturated fatty acids, undecanoate was the major one and $\mathrm{P} 3$ was the treatment with highest averages $(p<0.05)$. Hazelnut and cocoa, which are rich in this type of fatty acid (Lottenberg, 2009), were probably responsible for the elevation of saturated fatty acids in this treatment.

For a balanced intake of fatty acids, which are essential for health, the ratio between MUFA and SFA should be at least 0.45 and in this regard, was found that the P1, P2 and P3 spreads are respectively 4.33, 2.62 and 1.42 higher than this recommendation. In relation to this profile, it is estimated that the spreads may be effective in controlling the traditional risk factors for atherosclerotic cardiovascular disease (Lottenberg, 2009). The PUFA/SFA ratio should be as high as possible, preferably greater than 0.4 . To this end, no treatment reached the recommendation; however, $\mathrm{P} 1, \mathrm{P} 2$ and $\mathrm{P} 3$ obtained $0.52,0.55$ and $0.77 \%$ of it, respectively. This result was expected as baru almonds are not a matrix rich in polyunsaturated fatty acids (Campidelli et al., 2020).
As for the atherogenic index (AI), thrombogenic index $(\mathrm{TI})$ and $(\mathrm{h} / \mathrm{H})$ fatty acids, which indicate the potential for stimulation of platelet and coronary aggregation, the values obtained for P1, P2 and P3 were similar in all treatments $(p>0.05)$.

Although there is no established parameter for these indices, lower results for AI and TI, along with higher results for $\mathrm{h} / \mathrm{H}$ lessen the chance of coronary changes and make food healthier. This is due to the higher concentration of antiatherogenic fatty acids (Turan et al., 2007). Foods such as cheese and meat, which are substantial sources of fatty acids, have IA, IT and $\mathrm{h} / \mathrm{H}$ ratios of $2.32,3.11,1.23$ and 0.54 , $1.15,1.76$, respectively. Compared to spreads, they demonstrate superiority and better cardiovascular protection.

Żyżelewicz et al., (2018) found oleic (34.10\%), linoleic $(3.02 \%)$ and stearic $(35.93 \%)$ acids as the major fatty acids in chocolates made with $100 \%$ cocoa liquor.

\subsection{Mineral composition}

The determination of the mineral composition of phosphorus, calcium, magnesium, sulfur, manganese, zinc, boron, copper and iron present in food spreads supplemented with different levels of baru almonds, as well as the mineral RDI, are shown in Table 5 .

As can be observed, all treatments showed a significant difference $(p<0.05)$ for the analyzed minerals, showing that the variations in baru almonds and hazelnuts provided changes in these elements. It was found that the higher the baru almond content in the spread (P1), the higher the concentrations of phosphorus, calcium, magnesium, sulfur, manganese, zinc, boron and iron. Campidelli et al., (2019), analyzed the mineral composition of baru almonds, and found that they contained much higher amounts boron, magnesium, copper and manganese than the daily recommendation.

With regard to the phosphorus, iron and boron present in the P2 treatment, these elements are significantly $(p<0.05)$ similar to the P1 treatment, indicating that the use of $50 \%$ baru almonds and $50 \%$ hazelnuts can provide the same result as using only baru almonds.

Regardless of the oleaginous seed used, all almonds presented high levels of minerals (Institute of Medicine, 2000) because the consumption of 100 $\mathrm{g}$ allows for the ingestion of quantities superior to the 30\% that the reference RDI advocates.

Concentrations of phosphorus, calcium, magnesium, sulfur, manganese, zinc, boron, copper and iron may provide $5,2,5,2,15,5,5,27$ and 8 times this recommendation, respectively, suggesting that the spread developed developed has a high mineral composition. It is thus established that the consumption of these products should be 
Fatty acid profile, mineral content and bioactive compounds of cocoa $\bullet 9$

TABLE 4. Identification and quantification by high-performance liquid chromatography with diode-array detection (HPLC-DAD) of phenolic compounds present in food spreads made with different contents of baru almonds ${ }^{1}$

\begin{tabular}{|c|c|c|c|c|c|}
\hline \multirow[b]{2}{*}{ Phenolic Compound } & \multirow[b]{2}{*}{ Chemical Structure } & \multicolumn{4}{|c|}{ Treatments $\left(\mathrm{mg} .100 \mathrm{~g}^{-1}\right)^{(2)}$} \\
\hline & & P1 & $\mathbf{P 2}$ & P3 & $\mathbf{P}$ \\
\hline Gallic Acid & & $31.26 \pm 0.02^{\mathrm{a}}$ & $24.26 \pm 0.45^{\mathrm{b}}$ & $10.14 \pm 0.01^{\mathrm{c}}$ & 0.0070 \\
\hline Catechin & & $32.46 \pm 0.15^{\mathrm{a}}$ & $31.95 \pm 0.11^{\mathrm{a}}$ & $14.75 \pm 1.71^{\mathrm{b}}$ & 0.0001 \\
\hline Chlorogen Acid & & $8.80 \pm 0.01^{\mathrm{a}}$ & $7.61 \pm 0.08^{\mathrm{a}}$ & $1.31 \pm 0.16^{\mathrm{b}}$ & 0.0001 \\
\hline Caffeic Acid & & $0.93 \pm 0.01^{\mathrm{a}}$ & $0.60 \pm 0.02^{\mathrm{b}}$ & $0.16 \pm 0.11^{\mathrm{c}}$ & 0.0030 \\
\hline Vanillin & & $0.65 \pm 0.00^{\mathrm{b}}$ & $0.57 \pm 0.03^{\mathrm{b}}$ & $1.14 \pm 0.01^{\mathrm{a}}$ & 0.0001 \\
\hline$p$-coumaric & & - & - & $0.02 \pm 0.03$ & 0.0001 \\
\hline Ferrulic Acid & & - & $0.13 \pm 0.00^{\mathrm{b}}$ & $0.71 \pm 0.04^{\mathrm{a}}$ & 0.0001 \\
\hline$o$-coumaric & & - & - & $0.42 \pm 0.03$ & 0.0001 \\
\hline Trans-cinnamic Acid & & $1.70 \pm 0.13$ & $1.64 \pm 0.09$ & $1.55 \pm 0.08$ & 0.2389 \\
\hline Rutin & & $38.42 \pm 0.18^{\mathrm{b}}$ & $45.32 \pm 0.78^{\mathrm{a}}$ & $44.66 \pm 0.57^{\mathrm{a}}$ & 0.0001 \\
\hline Sum of phenolic compounds & & 114.22 & 112.08 & 74.86 & \\
\hline
\end{tabular}

${ }^{1}$ Mean values \pm standard deviation (in quadruple, $\left.n=4\right)$. Values followed by different letters in the same line show differences by Tukey's test at $95 \%$ significance ( $<<0.05) ;{ }^{2}$ Treatments: P1 (100\% baru almond and $0 \%$ hazelnuts), P2 $(50 \%$ baru almond and $50 \%$ hazelnuts) and P3 (0\% baru almond spread 100\% hazelnuts); ns: not significant at the level (p>0.05); P: p-value. 
$10 \bullet$ M.L.L. Campidelli et al.

TABLE 5. Identification and quantification by gas chromatography with flame-ionization detection (GC-FID) of fatty acids present in the alimentary spreads supplemented with different contents of baru almonds ${ }^{1}$

\begin{tabular}{|c|c|c|c|c|}
\hline \multirow[b]{2}{*}{ Fatty Acids $\left(\mathrm{g} \cdot 100 \mathrm{~g}^{-1}\right)$} & \multicolumn{4}{|c|}{ Treatments $^{2}$} \\
\hline & P1 & $\mathbf{P 2}$ & P3 & $\mathbf{P}$ \\
\hline Hexanoate & $0.03 \pm 0.00^{\mathrm{a}}$ & $0.03 \pm 0.00^{\mathrm{a}}$ & $0.02 \pm 0.00^{\mathrm{a}}$ & 0.10823 \\
\hline Octanoate & $1.64 \pm 0.09^{\mathrm{b}}$ & $1.71 \pm 0.15^{\mathrm{ab}}$ & $2.39 \pm 0.24^{\mathrm{a}}$ & 0.02947 \\
\hline Undecanoate & $15.50 \pm 0.56^{\mathrm{b}}$ & $16.55 \pm 2.06^{\mathrm{b}}$ & $26.58 \pm 2.50^{\mathrm{a}}$ & 0.01254 \\
\hline Laurate & $0.01 \pm 0.00^{\mathrm{a}}$ & $0.01 \pm 0.00^{\mathrm{a}}$ & $0.01 \pm 0.00^{\mathrm{a}}$ & 0.33029 \\
\hline Tridecanoate & $5.76 \pm 0.03^{\mathrm{a}}$ & $6.26 \pm 0.94^{\mathrm{a}}$ & $9.98 \pm 1.00^{\mathrm{a}}$ & 0.01152 \\
\hline Pentadecanoate & $0.01 \pm 0.00^{\mathrm{b}}$ & $0.01 \pm 0.00^{\mathrm{b}}$ & $0.02 \pm 0.00^{\mathrm{a}}$ & 0.00236 \\
\hline Palmitate & $0.13 \pm 0.01^{\mathrm{a}}$ & $0.09 \pm 0.01^{\mathrm{a}}$ & $0.09 \pm 0.01^{\mathrm{a}}$ & 0.08953 \\
\hline Methyl Behenate & $2.09 \pm 0.25^{\mathrm{b}}$ & $4.63 \pm 0.54^{\mathrm{a}}$ & $5.82 \pm 0.43^{\mathrm{a}}$ & 0.0001 \\
\hline Methyl Arachidate & $2.91 \pm 0.07^{\mathrm{b}}$ & $5.01 \pm 0.09^{\mathrm{a}}$ & $0.93 \pm 0.16^{\mathrm{c}}$ & 0.0001 \\
\hline Methyl Stearate & $3.67 \pm 0.21^{\mathrm{c}}$ & $6.89 \pm 0.08^{\mathrm{a}}$ & $5.01 \pm 0.12^{\mathrm{b}}$ & 0.0001 \\
\hline$\sum \mathrm{SFA}^{(3)}$ & $31.53 \pm 0.79^{\mathrm{b}}$ & $41.48 \pm 3.40^{\mathrm{b}}$ & $51.04 \pm 4.11^{\mathrm{a}}$ & 0.01009 \\
\hline Myristoleic & $0.11 \pm 0.03^{\mathrm{a}}$ & $0.11 \pm 0.02^{\mathrm{a}}$ & $0.13 \pm 0.01^{\mathrm{a}}$ & 0.10467 \\
\hline Heptadecanoate & $0.09 \pm 0.01^{\mathrm{a}}$ & $0.07 \pm 0.01^{\mathrm{a}}$ & $0.10 \pm 0.01^{\mathrm{a}}$ & 0.13281 \\
\hline Heptadecenoic acid & $3.35 \pm 0.08^{\mathrm{a}}$ & $4.05 \pm 0.51^{\mathrm{a}}$ & $4.70 \pm 0.42^{\mathrm{a}}$ & 0.09552 \\
\hline Octadecanoate & $0.06 \pm 0.02^{\mathrm{a}}$ & $0.081 \pm 0.02^{\mathrm{a}}$ & $0.10 \pm 0.02^{\mathrm{a}}$ & 0.13666 \\
\hline Oleic acid & $57.85 \pm 0.87^{\mathrm{a}}$ & $37.20 \pm 7.26^{\mathrm{b}}$ & $27.52 \pm 7.60^{\mathrm{b}}$ & 0.00707 \\
\hline Eicosenoate acid & $0.14 \pm 0.00^{\mathrm{c}}$ & $0.76 \pm 0.51^{\mathrm{b}}$ & $1.75 \pm 0.46^{\mathrm{a}}$ & 0.00016 \\
\hline Erucate acid & $0.05 \pm 0.00^{\mathrm{b}}$ & $0.05 \pm 0.00^{\mathrm{b}}$ & $0.10 \pm 0.00^{\mathrm{a}}$ & 0.00638 \\
\hline$\sum$ MUFA $^{(4)}$ & $61.63 \pm 1.10^{\mathrm{a}}$ & $49.14 \pm 6.18^{\mathrm{a}}$ & $32.83 \pm 6.88^{\mathrm{a}}$ & 0.53647 \\
\hline Linoleate acid & $6.66 \pm 0.03^{\mathrm{b}}$ & $9.24 \pm 2.02^{\mathrm{b}}$ & $13.46 \pm 1.91^{\mathrm{a}}$ & 0.00643 \\
\hline Gamma-linolenic acid & $0.12 \pm 0.00^{\mathrm{c}}$ & $0.26 \pm 0.29^{\mathrm{b}}$ & $1.05 \pm 0.26^{\mathrm{a}}$ & 0.00024 \\
\hline Docosadienoic acid & $0.06 \pm 0.01^{\mathrm{c}}$ & $0.87 \pm 0.50^{\mathrm{b}}$ & $1.61 \pm 0.45^{\mathrm{a}}$ & 0.00017 \\
\hline$\sum$ PUFA $^{(5)}$ & $6.84 \pm 0.05^{\mathrm{b}}$ & $9.38 \pm 2.81^{\mathrm{b}}$ & $16.13 \pm 2.64^{\mathrm{a}}$ & 0,003 \\
\hline PUFA/SFA ${ }^{(6)}$ & $0.21 \pm 0.00^{\mathrm{b}}$ & $0.22 \pm 0.06^{\mathrm{b}}$ & $0.31 \pm 0.05^{\mathrm{a}}$ & 0.00329 \\
\hline MUFA/SFA $^{(7)}$ & $1.95 \pm 0.14^{\mathrm{a}}$ & $1.18 \pm 0.56^{\mathrm{b}}$ & $0.64 \pm 0.65^{\mathrm{c}}$ & 0.00532 \\
\hline $\mathrm{TI}^{(8)}$ & $0.01 \pm 0.00^{\mathrm{a}}$ & $0.01 \pm 0.00^{\mathrm{a}}$ & $0.01 \pm 0.00^{\mathrm{a}}$ & 0.1643 \\
\hline $\mathrm{AI}^{(9)}$ & $0.05 \pm 0.00^{\mathrm{a}}$ & $0.06 \pm 0.00^{\mathrm{a}}$ & $0.06 \pm 0.00^{\mathrm{a}}$ & 0.36538 \\
\hline $\mathrm{h} / \mathrm{H}^{(10)}$ & $489.77 \pm 36.57^{\mathrm{a}}$ & $510.15 \pm 21.48^{\mathrm{a}}$ & $508.24 \pm 19.23^{\mathrm{a}}$ & 0.3455 \\
\hline
\end{tabular}

${ }^{1}$ Mean values \pm standard deviation (in quadruple, $n=4$ ). Values followed by different letters in the same line show differences by Tukey's test at $95 \%$ significance $(\mathrm{p}<0.05)$; ${ }^{2}$ Treatments: P1 $(100 \%$ baru almond and $0 \%$ hazelnuts), P2 $(50 \%$ baru almond and $50 \%$ hazelnuts) and P3 (0\% baru almond spread and 100\% hazelnuts); ${ }^{3}$ Total saturated fatty acids; ${ }^{4}$ Total unsaturated fatty acids; ${ }^{5}$ Total of polyunsaturated fatty acids; ${ }^{6}$ Relationship between saturated and polyunsaturated fatty acids; ${ }^{7}$ Relationship between saturated and unsaturated fatty acids; ${ }^{8}$ Thrombogenic index; ${ }^{9}$ Atherogenic index; ${ }^{10}$ hypocholesterolemic/hypercholesterolemic potential; P: $p$ - value.

promoted because they supply the RDI of different minerals and can contribute to health and nutrition. In general, oleaginous plants have high levels of minerals and baru almonds are among the most outstanding.

\subsection{Principal components analysis and hierarchical cluster analysis}

Due to the relatively high number of variables studied, a principal component analysis (PCA) was performed to elucidate the characteristics related to these variables, correlating them and grouping them with the treatments used (P1, P2 and P3).
Figure 1 shows the PCA results for bioactive compound and phenolic compound profiles. The first two main components explained $100 \%$ of the total variation between treatments for these compounds, and the first component explained $88.37 \%$ of this variation.

The spatial separation of the formulations shows that the formulation of the spreads with different contents of baru almonds differed with respect to bioactive compounds and phenolic compounds. Moreover, formulation P3 presented higher values for vanillin variables, $p$-coumatic ferrulic, DPPH, and rutin. Formulation P1 presented higher values for the variables beta-carotene/linoleic acid, 
TABLE 6. Average values of the mineral composition of food spreads supplemented with different levels of baru almonds ${ }^{1}$

\begin{tabular}{|c|c|c|c|c|c|}
\hline \multirow[b]{2}{*}{ Minerals } & \multicolumn{5}{|c|}{ Treatments $\left(\mathrm{mg} \cdot 100 \mathrm{~g}^{-1}\right)^{2}$} \\
\hline & P1 & $\mathbf{P 2}$ & P3 & $\mathbf{P}$ & $\mathrm{RDI}^{3}\left(\mathrm{mg} .100 \mathrm{~g}^{-1}\right)$ \\
\hline Phosphor & $4100 \pm 0.23^{\mathrm{ba}}$ & $4000 \pm 0.44^{\mathrm{a}}$ & $3600 \pm 0.93^{\mathrm{b}}$ & 0.0127 & 700 \\
\hline Calcium & $3500 \pm 2.33^{\mathrm{a}}$ & $2500 \pm 1.03^{\mathrm{b}}$ & $2300 \pm 1.44^{\mathrm{b}}$ & 0.0004 & 1000 \\
\hline Magnesium & $1700 \pm 1.03^{\mathrm{a}}$ & $1400 \pm 1.92^{\mathrm{b}}$ & $1200 \pm 1.96^{\mathrm{c}}$ & 0.0011 & 260 \\
\hline Sulfur & $2000 \pm 0.45^{\mathrm{a}}$ & $1800 \pm 0.32^{\mathrm{b}}$ & $1600 \pm 0.93^{\mathrm{c}}$ & 0.0003 & 850 \\
\hline Manganese & $52.7 \pm 0.96^{\mathrm{a}}$ & $35.6 \pm 0.86^{\mathrm{b}}$ & $20.8 \pm 0.98^{\mathrm{c}}$ & 0.0000 & 2.3 \\
\hline Zinc & $35.1 \pm 0.95$ & $40.6 \pm 0.65^{\mathrm{a}}$ & $43.2 \pm 0.74^{\mathrm{a}}$ & 0.0012 & 7 \\
\hline Boron & $19.8 \pm 0.99^{\mathrm{a}}$ & $18.4 \pm 2.30^{\mathrm{a}}$ & $10.2 \pm 3.55^{\mathrm{b}}$ & 0.0067 & 3 \\
\hline Copper & $15.9 \pm 2.84^{\mathrm{b}}$ & $29.4 \pm 3.45^{\mathrm{a}}$ & $29.4 \pm 0.95^{\mathrm{a}}$ & 0.0000 & 0.9 \\
\hline Iron & $125.9 \pm 3.04^{\mathrm{a}}$ & $132.4 \pm 3.92^{\mathrm{a}}$ & $106.4 \pm 2.95^{\mathrm{b}}$ & 0.0000 & 14 \\
\hline
\end{tabular}

${ }^{1}$ Mean values \pm standard deviation (in quadruple, $\mathrm{n}=4$ ). Values followed by different letters in the same line show differences by Tukey's test at $95 \%$ significance $(\mathrm{p}<0.05)$; ${ }^{2}$ Treatments: P1 $(100 \%$ baru almond and $0 \%$ hazelnuts), P2 $(50 \%$ baru almond and $50 \%$ hazelnuts) and P3 (0\% baru almond spread 100\% hazelnuts); ${ }^{3}$ Recommended Diary Ingestion (BRASIL, 2005).

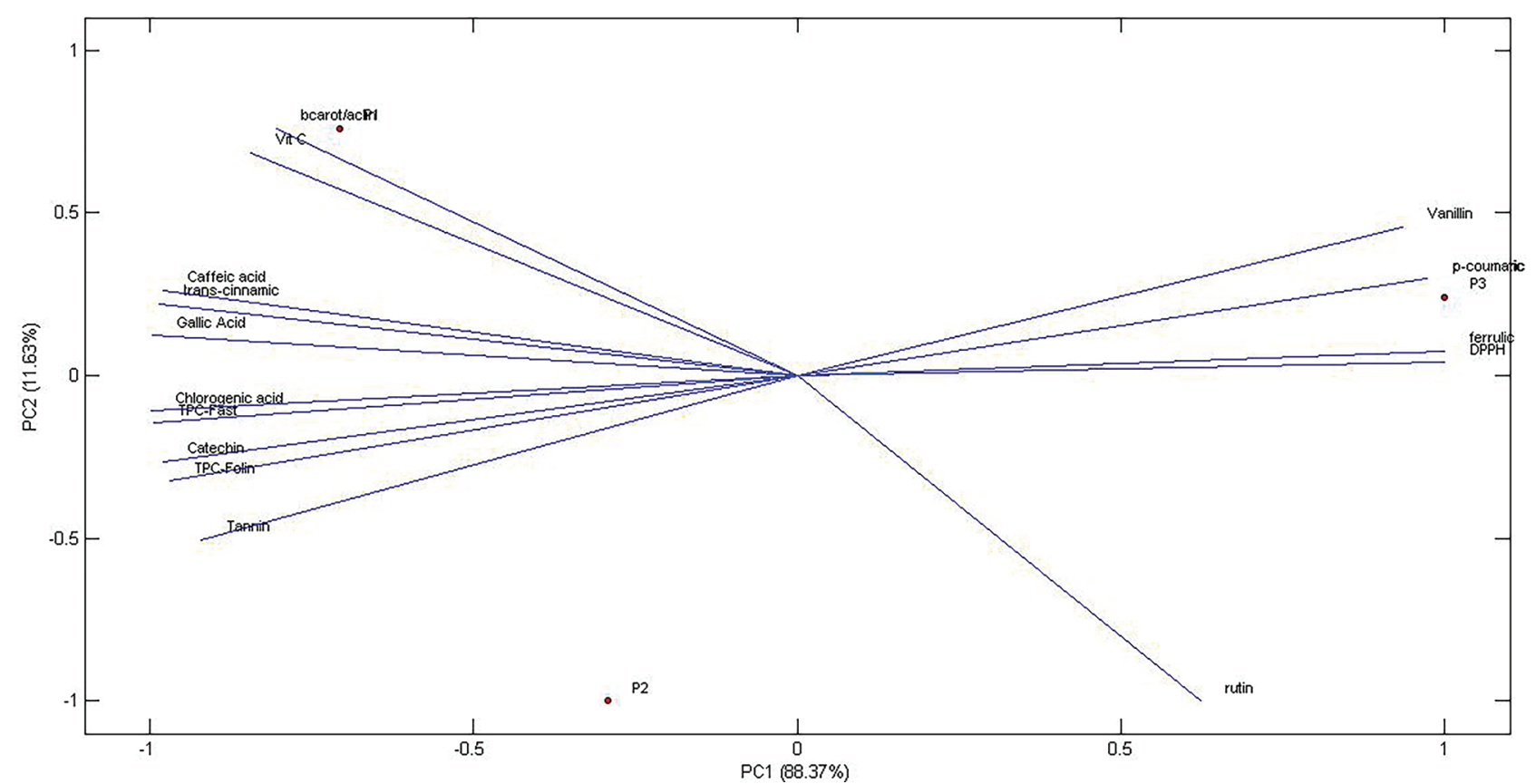

Figure 1. Principal Component (PC) 1 and 2 score chart for food spreads supplemented with different levels of baru almonds.

vitamin c, caffeic acid, trans-cinnamic, gallic acid, chlorogenic acid, total phenolic compounds (Fast method), catechin, total phenolic compounds (Folin method), and tannin and formulation P2 presented intermediate values for the analyzed variables.

\section{CONCLUSIONS}

The addition of baru almonds ( $\mathrm{P} 1$ treatment) enhanced the concentrations of vitamin $\mathrm{C}$, antioxidants, gallic acid, calcium, magnesium, sulfur, manganese and oleic acid. In contrast, the absence of this oil in the P3 treatment increased the concentrations of vanillin, $p$-coumaric, ferric, $o$-coumaric, linoleic acid and saturated and polyunsaturated fatty acids. When tannins, beta-carotene/linoleic acid, trans-cinnamic acid, monounsaturated fatty acids, hypocholesterolemic and hypercholesterolemic fatty acids content and atherogenic and thrombogenic indices were evaluated, no significant $(p>0.05)$ differences were detected between treatments.

\section{ACKNOWLEDGMENTS}

We appreciate the assistance of the Council for Scientific and Technological Development (CNPq; 304724 / 2013-01), the Minas Gerais Research Foundation (FAPEMIG; CAG-APQ-00798-16 
and PPM-00458-15) and the Coordination of Improvement of Personnel in Higher Education (CAPES; Procad - 88881.06.8456 / 2014-01) for their help in the execution of this research.

\section{REFERENCES}

AOAC. 1990. Official methods of analysis of AOAC international, 15th ed. Washington, DC, USA: Association of Official Analytical Chemists. p. 1990.

Campidelli MLL, Souza JDC, Sousa EC, Magalhães ML, Nunes EEC, Faria PB, Franco M, Vilas Boas EVB. 2020. Effects of the drying process on the fatty acids, phenolic profile, tocopherols and antioxidants activity of baru almonds (Dipteryx alata Vog.). Grasas Aceites 71 (1), e343. https://doi.org/10.3989/gya.1170182

Campidelli MLL, Carneiro JDS, Sousa EC, Magalhães ML, Konig IFM, Braga MA, Orlando TM, Simão SD, Lima LMZ, Vilas Boas EVB. 2019. Impact of the Drying Process on the Quality and Physicochemical and Mineral Composition of Baru Almonds (Dipteryx Alata Vog.) Impact of the Drying Process on Baru Almonds. J. Cul. Sci. Tech. 200, 1-13. https://doi.org/10.1080/15428052.2019.1573710

Chu X, Wang H, Jiang Y, Zhang Y, Bao Y, Zhang X. 2016. Ameliorative effects of tannic acid on carbon tetrachloride-induced liver fibrosis in vivo and in vitro. $J$. Pharmacol. Sci. 130, 15-23. https://doi.org/10.1016/j. jphs.2015.12.002

Dillinger TL, Barriga P, Escárcega S, Jimenez M, Lowe DS, Grivetti LE. 2000. Food of the gods: cure for humanity? A cultural history of the medicinal and ritual use of chocolate. J. Nutr. 130, 2057-2072. http://doi.org/10.1093/ jn/130.8.2057S

Efraim P, Alves AB, Jardim DCP. 2011. Polifenóis em cacau e derivados: teores, fatores de variação e efeitos na saúde. Braz. J. Food Technol. 14, 181-201.

Folch J, Lees M, Stanley SA. 1957. A simple method for isolation and purification of total lipids from animal tissues. J. Biol. Chem. 226, 479-503.

Giacometti J, Muhvic D, Pavletić A, Đudarić L. 2016. Cocoa polyphenols exhibit antioxidant, anti-inflammatory, anticancerogenic, and anti-necrotic activity in carbon tetrachloride- intoxicated mice. J. Funct. Foods 23, 177-187. https://doi.org/10.1016/j.jff.2016.02.036

Hassimoto NM, Genovese IS, Lajolo FM. 2005. Antioxidant activity of dietary fruits, vegetables and commercial frozen fruit pulps. J. Agric. Food Chem. 53, 2928-2935. https://doi. org/10.1021/jf047894h

Herbello-Hermelo P, Lamas JP, Lores M, Domínguez-González R, Bemejo-Barrera P, Moreda-Pinero A. 2018. Polyphenol bioavailability in nuts and seeds by an in vitro dialyzability approach. Food Chem. 254, 20-25. https://doi.org/ 10.1016/j.foodchem.2018.01.183

Hernández-Hernández C, Viera-Alcaide I, Morales-Sillero AM, Fernández-Bolaños J, Rodríguez-Gutiérrez G. 2018. Bioactive compounds in Mexican genotypes of cocoa cotyledon and husk. Food Chem. 240, 831-839. https://doi. org/10.1016/j.foodchem.2017.08.018

Holzhauser T, Stephan O, Vieths S. 2002. Detection of potentially allergenic hazelnut (Corylus avellana) residues in food: a comparative study with DNA P CR - ELISA and protein Sandwich-Elisa. J. Agric. Food Chem. 50, 5808-5815. https://doi.org/10.1021/jf025600r

Institute of Medicine. 2000. Food and Nutrition Board. Dietary Reference Intake for Vitamin C, Vitamin E, Selenium and Carotenoids. Washington, DC, USA: National Academy Press; 2000. https://doi.org/10.17226/9810
Kornsteiner M, Karl-Heinz W, Elmadfa I. 2006. Tocopherols and total phenolics in 10 different nut types. Food Chem. 98 , 381-387. https://doi.org/10.1016/j.foodchem.2005.07.033

Lemos MRB, Zambiazi RC, de Almeida EM, de Alencar ER. 2016. Tocopherols and Fatty Acid Profile in Baru Nuts (Dipteryx Alata Vog.), Raw and Roasted: Important Sources in Nature that Can Prevent Diseases. Food Sci. Nutr. Technol. 1, 1-11.

Lottenberg AMP. 2009. Importance of the dietary fat on the prevention and control of metabolic disturbances and cardiovascular disease. Arq. Bras. Endocrinol. Metab. 53, 595607. https://doi.org/10.1590/S0004-27302009000500012

Milardovic S, Ivekovic D, Grabaric BS. 2006. A novel amperometric method for antioxidant activity determination using DPPH free radical. Bioelectrochemistry 68, 175-180. https://doi.org/10.1016/j.bioelechem.2005.06.005

Miller HE. 1971. A simplified method for the evaluation of antioxidant. J. Am. Oil Chem. Soc. 48, 91-97. https://doi.org/ 10.1007/BF02635693

Naczk M, Shahidi F. 2004. Extraction and analysis of phenolics in food. J. Chromatogr. A 1054, 95-111. https://doi.org/ 10.1016/S0021-9673(04)01409-8

Nunes CA, Freitas MP Pinheiro ACM Bastos SC 2012. Chemoface: 137 a novel free user-friendly interface for chemometrics. J. Braz. Chem. Soc. 23, 2003-2010. http://doi. org/10.1590/S0103-50532012005000073

Palombini SV, Claus T, Maruyama SA, Carbonera F, Montanher PF, Visentainer JV, Matsushita M. 2016. Optimization of a New Methodology for Determination of Total Phenolic Content in Rice Employing Fast Blue $\mathrm{BB}$ and QUENCHER Procedure. J. Braz. Chem. Soc. 7, 1188-1194. https://doi.org/10.5935/0103-5053.20160013

Pelvan E, Okten O, Karadag A, Alasalvar C. 2018. Phenolic profiles and antioxidant activity of Turkish Tombul hazelnut samples (natural, roasted, and roasted hazelnut skin). Food Chem. 244, 102-108. https://doi.org/10.1016/j. foodchem.2017.10.011

Pineli L de O, de Carvalho MV, de Aguiar LA, de Oliveira GT, Celestino SMC, Botelho RBA, Chiarello MD. (2015). Use of baru (Brazilian almond) waste from physical extraction of oil to produce flour and cookies. LWT 60, 50-55. https://doi.org/10.1016/j.lwt.2014.09.035

Roe JH, Kuether CA. 1943. The determination of ascorbic acid in whole blood and urine through the 2,4-dinitrophenylhydrazine derivative of dehydroascorbic acid. J. Biol. Chem. 147, 399-407.

Santos-Silva J, Bessa RJB, Santos-Silva F. 2002. Effects of genotype, feeding system and slaughter weigt on the quality of light lambs. Fatty acid composition of meat. Livest. Sci. 77, 187-194. https://doi.org/10.1016/S0301-6226(01)00334-7

Sarruge JR, Haag HP, editors. 1974. Análises químicas em plantas. Piracicaba, Brasil: Esalq; 1974.

Souza RGM, Gomes AC, Castro IA, Mota JF. 2018. A baru almond-enriched diet reduces abdominal adiposity and improves high-density lipoprotein concentrations: a randomized, placebo-controlled trial. Nutr. 56, 154-160. https://doi.org/10.1016/j.nut.2018.06.001

Traber MG, Stevens JF. 2011. Vitamins C and E: beneficial effects fromamechanistic perspective. Free Radic. Biol. Med. 51, 1000-1013. https://doi.org/10.1016/j.freeradbiomed.2011.05.017

Ulbricht TLV, Southgate DAT. 1991. Coronary Heart Disease: Seven Dietary Factors. Lancet 338, 985-992. https://doi. org/10.1016/0140-6736(91)91846-M

Żyżelewicz D, Budryn G, Oracz J, Antolak H, Kręgiel D, Kaczmarska M. 2018. The effect on bioactive components and characteristics of chocolate by functionalization with raw cocoa beans. Food Research International 113, 234-244. https://doi.org/10.1016/j.foodres.2018.07.017 